ScIDice

\section{Prevalence and Associated Factors of Maxillary Canine Transposition in Subjects Visiting a University Hospital Setup}

Research Article

Trishala A ${ }^{1}$, Ravindra Kumar Jain ${ }^{2 *}$, Arthi $B^{3}$

${ }^{1}$ Saveetha Dental College and Hospital, Saveetha Institute of Medical and Technical Sciences, Saveetha University, Chennai 600077, Tamil Nadu, India. ${ }^{2}$ Reader, Department of Orthodontics, Saveetha Dental College and Hospital, Saveetha Institute of Medical and Technical Sciences, Saveetha University, Chennai 600077, Tamil Nadu, India.

${ }^{3}$ Associate Professor, Department of Public Health Dentistry, Saveetha Dental College and Hospital, Saveetha Institute of Medical and Technical Sciences, Saveetha University, Chennai 600077, Tamil Nadu, India.

\title{
Abstract
}

Tooth transposition is defined as a type of eruption anomaly where there is either an exchange of position between two adjacent teeth, or the development and eruption of a tooth in a position normally occupied by another non-adjacent tooth. The canine is one of the most commonly involved teeth in the transposition phenomenon. Early diagnosis of a developing transposition is extremely important and has a great influence on prognosis. The aim of this study was to assess the prevalence of maxillary canine transposition among patients visiting a private dental college. A retrospective study was conducted using the patient records from Saveetha Dental College, Chennai from June 2019 - April 2020. The study population included case records of patients who reported for orthodontic treatment. Records of 986 patients were screened for transposition of maxillary canines and it was found that only 6 patients had maxillary canine transposition. Data was collected and then subjected to statistical analysis. Microsoft Excel 2016 (Microsoft office 10) data spreadsheet was used to collect data and later exported to SPSS IBM (version 20.0). Descriptive statistics and chi square test were employed with a level of significance set at $\mathrm{p}<0.05$. About $59.4 \%$ of the patients who reported for orthodontic treatment were adolescents between the age group of $15-20$ years and $40.6 \%$ were adults between $20-45$ years. $48.02 \%$ were male patients and $51.98 \%$ were females. The overall prevalence of maxillary canine transposition was $0.61 \%$. The site of transposition was greater in lateral incisors $(66.67 \%)$ followed by premolars $(33.33 \%)$. There was a greater prevalence of maxillary canine transposition among adults, female population and patients with class I malocclusion, however it was not statistically significant $(\mathrm{p}>0.05)$

Keywords: Lateral Incisor; Maxillary Canine Transposition; Malocclusion; Premolar.

\section{Introduction}

Oral health is an integral part of general health [19]. Dentofacial appearance has a lot to do with the way the people are perceived in the society [14]. Adolescents with significant dentofacial inharmonies are considered at risk for negative self-esteem and social maladjustments $[18,55]$. Malocclusion is regarded as an irregularity of the teeth or a mal-relationship between the dental arches beyond the normal range [46].

Severe malocclusion can be a social handicap [25]. Malocclusion can cause different problems for the patient, such as psychosocial problem related to impaired dentofacial esthetics, problems with oral functions including difficulty in jaw movements, temporomandibular joint disturbances, difficulty in mastication, swallowing and speech, greater susceptibility to trauma and accentuated periodontal disease $[62,23,63]$.

The prevalence of malocclusion varies in different parts of the world among various populations [16, 44, 22]. Knowledge about the distribution of different malocclusions may help orthodontic practitioners better understand the existent problem in a geographic location and help them in the proper orientation and management of treatment possibilities $[32,42,17]$.

Transposition is a relatively rare dental anomaly, characterized by

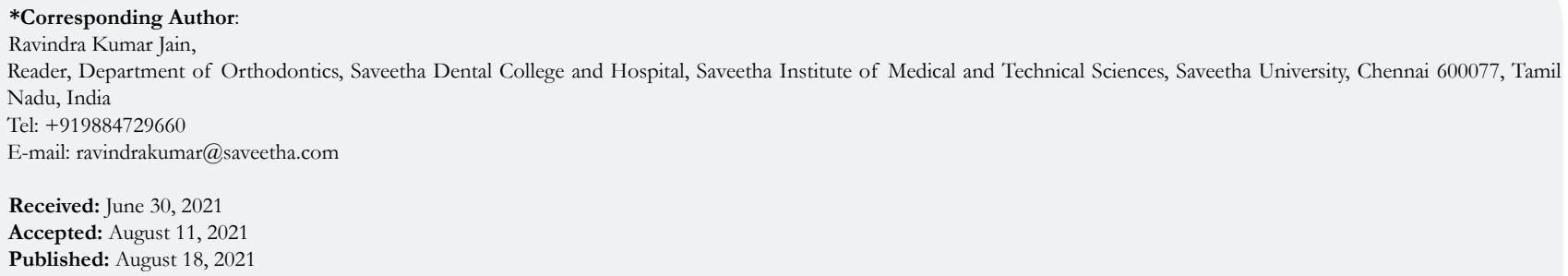

Copyright: Ravindra Kumar Jain 2021 . This is an open-access article distributed under the terms of the Creative Commons Attribution License, which permits unrestricted use, distribution and reproduction in any medium, provided the original author and source are credited. 
an interchange in the position of two adjacent permanent teeth on the same side of the dental arch [35]. It is identified as complete transposition when the crowns and the roots of the involved teeth exchange places in the dental arch; and incomplete transposition when the crowns are transposed but the roots remain in their normal positions [26].

Tooth transposition generally occurs in the maxilla and is often associated with other dental anomalies, such as agenesis, retained primary canine and peg-shaped or small maxillary lateral incisors [49]. Transpositions affect both sexes, but female patients have been reported to outnumber male patients in the prevalence of this anomaly [50]. The condition may occur both unilaterally or bilaterally, but a greater incidence of unilateral cases has been reported. Left side dominance has also been reported [12]. The canine is one of the most commonly involved teeth in the transposition phenomenon. Because of the high incidence of retained deciduous canines associated with tooth transposition, some authors report deciduous teeth as being the primary etiologic factor of this anomaly. The intraosseous migration of the canine, trauma to the deciduous tooth, and the presence of cysts and pathologies have also been suggested [27]. The canine shows the highest incidence of transposition with the first premolar, less often with the lateral incisor, rarely with the central incisor and extremely rarely with the second premolar or first molar [10].

Transpositions were classified according to Peck et al. [36] as

Maxillary canine-first premolar (Mx.C.P1)

Maxillary canine-lateral incisor (Mx.C.I2)

Maxillary canine to first molar site (Mx.C to M1)

Maxillary lateral incisor-central incisor (Mx.I2.I1)

Maxillary canine to central incisor site (Mx.C to I1)

Mandibular lateral incisor-canine (Mnd.I2.C)

Early diagnosis of a developing transposition is extremely important and has a great influence on prognosis [58]. This may usually be performed by a conventional panoramic radiographic examination when the patient is between 6 and 8 years of age [6]. When the alteration is detected early, interceptive procedures including extraction of deciduous teeth and placement of eruption guides for the permanent teeth may be performed, thus preventing complete development of the anomaly. On the other hand, when transposition is detected at a later stage, orthodontic planning must address the indications for against extraction and the sequence of correcting tooth positioning [66]. Previously our team has a rich experience in working on various research projects across multiple disciplines. (Muthukrishnan and Warnakulasuriya 2018 [30]); (Govindaraju, Neelakantan, and Gutmann 2017 [21]); (Chen et al. 2019 [11]); (Priyanka et al. 2017[39]); (Sitharthan et al. 2019 [54]); (Priyadharsini et al. 2018 [61]); (Azeem and Sureshbabu 2018 [4]); (Wu et al. 2019 [65]); (Abitha and Santhanam 2019) [1]; (Manohar and Abilasha 2019 [28]); (Venu, Dhana Raju, and Subramani 2019 [59]); (Wang et al. 2019 [64]); (Girija, Jayaseelan, and Arumugam 2018 [20]); (Sheriff, Ahmed Hilal Sheriff, and Santhanam 2018 [53]); (Dhinesh et al. 2017 [13]). Now the growing trend in this area motivated us to pursue this project.

The aim of this study was to assess the prevalence of maxillary canine transposition in subjects visiting a university hospital setup.

\section{Materials and Methods}

\section{Study design and setting:}

This pilot retrospective study examined the case records of patients who underwent treatment from June 2019 - April 2020 at Saveetha dental college, Chennai. The study population included case records of orthodontic patients, selected by non-probability purposive sampling. Pediatric patients with primary dentition, completely edentulous patients and denture wearers were excluded from the study.

\section{Ethical approval:}

Ethical approval was obtained from the Institutional Ethics Committee of the University (SDC/SIHEC/2020/DIASDATA/0619-0320).

\section{Data collection:}

Records of 986 patients who reported for orthodontic treatment were reviewed and analysed. Relevant data such as patient age, sex, type of malocclusion, prevalence of maxillary canine transposition and site of transposition were recorded. Repeated patient records and incomplete records were excluded. Data was verified by an external reviewer.

\section{Statistical analysis:}

Data was recorded in Microsoft Excel 2016 (Microsoft office 10) and later exported to the Statistical Package for Social Science (SPSS IBM version 20.0) and subjected to statistical analysis. Descriptive statistics and chi square test were employed with a level of significance set at $\mathrm{p}<0.05$.

\section{Results \& Discussion}

The data for this retrospective study was based on residents of Chennai seeking treatment at a University hospital setup in Chennai. This study aims to elucidate the importance of early diagnosis of transposition and appropriate intervention to provide the best aesthetic and functional outcome.

About $59.4 \%$ of the patients who reported for orthodontic treatment were adolescents between the age group of 15-20 years and $40.6 \%$ were adults between $20-45$ years [Figure 1].

$48.02 \%$ were male patients and $51.98 \%$ were females [Figure 2]. The overall prevalence of maxillary canine transposition was $0.61 \%$ [Figure 3].

The site of transposition was greater in lateral incisors $(66.67 \%)$ followed by premolars (33.33\%) [Figure 4].

There was no significant association between age and maxillary canine transposition ( $\mathrm{p}>0.05)$, but there was a higher prevalence among adults $(0.41 \%)$ when compared to adolescents $(0.2 \%)$ [Figure 5 , Table 1].

$0.41 \%$ of females and $0.2 \%$ of males had maxillary canine transposition, showing a female predilection. However there was no 
Table 1 represents the association between age, gender, type of malocclusion and prevalence of maxillary canine transposition. There was a higher prevalence of maxillary canine transposition among adults $(0.41 \%)$, males $(0.41 \%)$ and patients with class one malocclu$\operatorname{sion}(0.41 \%)$. However, Chi square test showed no significant association.

\begin{tabular}{|c|c|c|c|c|}
\hline & \multicolumn{2}{|c|}{$\begin{array}{l}\text { Prevalence of maxil- } \\
\text { lary canine transposi- } \\
\text { tion }\end{array}$} & \multirow[t]{2}{*}{$\begin{array}{l}\text { Pearson Chi } \\
\text { square value }\end{array}$} & \multirow[t]{2}{*}{ P-value } \\
\hline & $\begin{array}{c}\text { Present } \\
(\%)\end{array}$ & $\begin{array}{c}\text { Absent } \\
(\%)\end{array}$ & & \\
\hline \multicolumn{5}{|l|}{ Age : } \\
\hline Adolescents & $0.20 \%$ & $59.17 \%$ & 1.697 & $\begin{array}{c}0.193,(\mathrm{p}>0.05, \text { statistically } \\
\text { insignificant) }\end{array}$ \\
\hline Adults & $0.41 \%$ & $40.22 \%$ & & \\
\hline \multicolumn{5}{|l|}{ Gender: } \\
\hline Male & $0.41 \%$ & $47.62 \%$ & 0.841 & $\begin{array}{c}0.359,(p>0.05, \text { statistically } \\
\text { insignificant })\end{array}$ \\
\hline Female & $0.20 \%$ & $51.77 \%$ & & \\
\hline \multicolumn{5}{|c|}{$\begin{array}{l}\text { Type of malocclu- } \\
\text { sion : }\end{array}$} \\
\hline Class I & $0.41 \%$ & $63.32 \%$ & & $\begin{array}{c}0.877,(p>0.05, \text { statistically } \\
\text { insignificant })\end{array}$ \\
\hline Class II & $0.20 \%$ & $31.91 \%$ & 0.262 & \\
\hline Class III & $0 \%$ & $4.15 \%$ & & \\
\hline
\end{tabular}

Figure 1: Bar graph representing the age distribution of patients included in this study. $\mathrm{X}$ axis represents the age of patients and $\mathrm{Y}$ axis represents the total percentage of patients included in this study. About $59.4 \%$ of the patients who reported for orthodontic treatment were adolescents between the age group of $15-20$ years and $40.6 \%$ were adults between $20-45$ years.

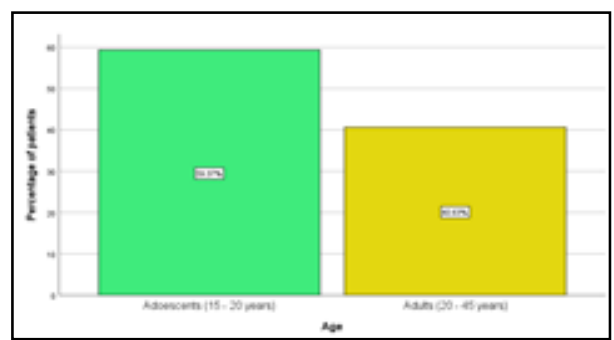

Figure 2: Bar graph representing the gender distribution. $\mathrm{X}$ axis represents the gender of patients and $\mathrm{Y}$ axis represents the total percentage of patients included in this study. $48.02 \%$ were male patients and $51.98 \%$ were females.

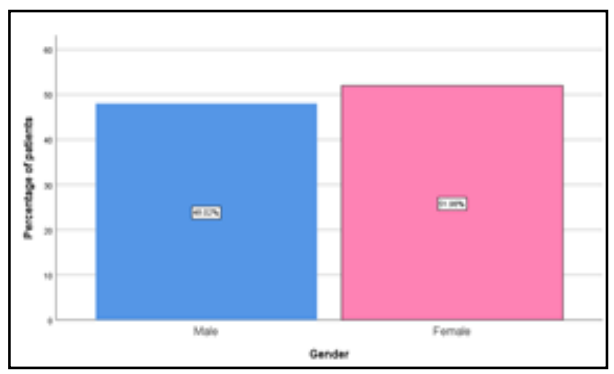

Figure 3: Bar graph depicting the overall prevalence of maxillary canine transposition. $X$ axis represents the prevalence of maxillary canine transposition and $\mathrm{Y}$ axis represents the total percentage of patients included in this study. The overall prevalence of maxillary canine transposition was $0.61 \%$ (purple).

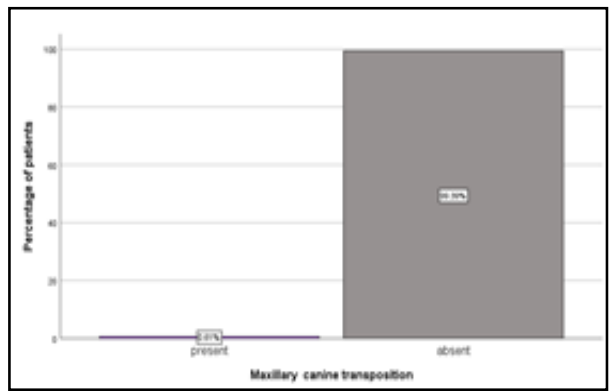


Figure 4: Bar graph representing the prevalence of maxillary canine transposition among lateral incisors and premolars. $\mathrm{X}$ axis represents the site of maxillary canine transposition and $\mathrm{Y}$ axis represents the total percentage of patients with maxillary canine transposition. The site of transposition was greater in lateral incisors $-66.67 \%$ (green) followed by premolars $-33.33 \%$ (orange).

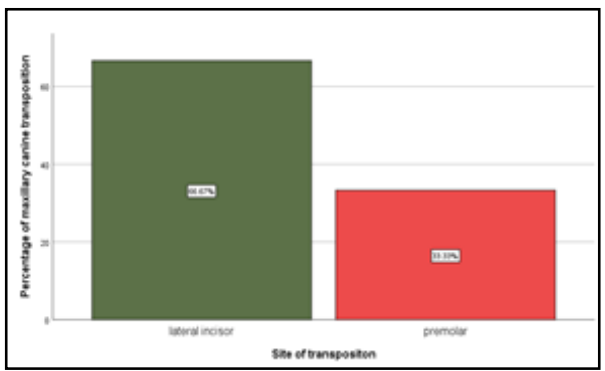

Figure 5: Bar graph representing the association between age and the prevalence of maxillary canine transposition. $\mathrm{X}$ axis represents the age of the patients and $\mathrm{Y}$ axis represents the number of patients included in this study. About $0.2 \%$ of adolescents and $0.41 \%$ of adults had maxillary canine transposition. Chi square test was done and it was found to be statistically insignificant. Pearson Chi square value $=1.697 ; \mathrm{p}-\mathrm{value}=0.193(\mathrm{p}>0.05, * \mathrm{statistically}$ insignificant). The prevalence of maxillary canine transposition (purple) was higher among adults when compared to adolescents.

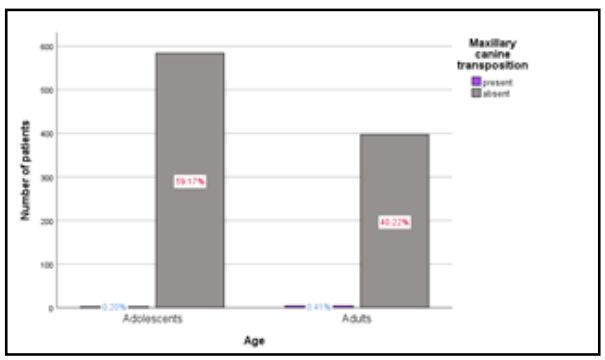

Figure 6: Bar graph representing the association between gender and the prevalence of maxillary canine transposition. $\mathrm{X}$ axis represents the gender of patients and $\mathrm{Y}$ axis represents the prevalence of maxillary canine transposition. About $0.2 \%$ of females and $0.41 \%$ of males had maxillary canine transposition. Chi square test was done and it was found to be statistically insignificant. Pearson Chi square value $=0.841 ; p-v a l u e=0.359(p>0.05, *$ statistically insignificant). Males had a higher prevalence of maxillary canine transposition (purple) when compared to females.

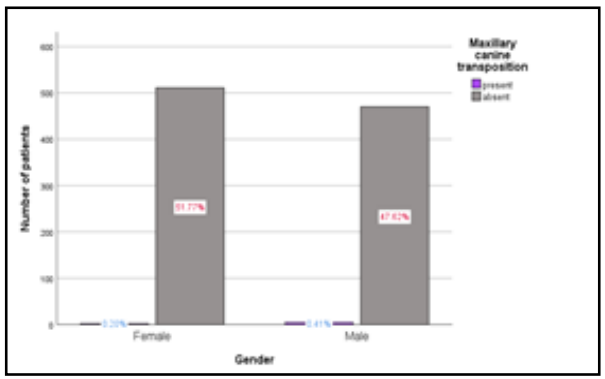

Figure 7: Bar graph representing the association between type of malocclusion and the prevalence of maxillary canine transposition. $\mathrm{X}$ axis represents the various types of malocclusion and $\mathrm{Y}$ axis represents the total number of patients included in this study. About $0.41 \%$ of patients with class I malocclusion and $0.2 \%$ of patients with class 2 malocclusion had maxillary canine transposition. Chi square test was done and it was found to be statistically insignificant. Pearson Chi square value $=0.262$; $\mathrm{p}$-value $=0.877$ ( $>0.05$, *statistically insignificant). There was a higher prevalence of maxillary canine transposition (purple) among patients with class I malocclusion followed by patients with class II malocclusion and no reported cases in patients with class III malocclusions.

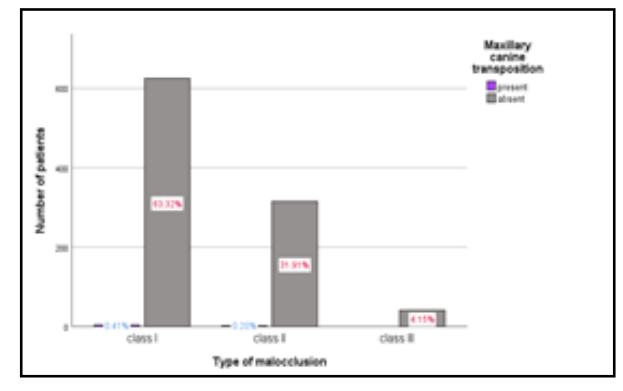

significant association $(\mathrm{p}>0.05)$ [Figure 6, Table 1].

There was a higher prevalence of maxillary canine transposition among patients with class I malocclusion $(0.41 \%)$, followed by class II $(0.2 \%)$ and there were no reported cases of maxillary canine transposition in class III malocclusion. There was no significant association between the type of malocclusion and the prevalence of maxillary canine transposition $(\mathrm{p}>0.05)$ [Figure 7 , Table 1].
The overall prevalence of maxillary canine transposition in the present study was $0.61 \%$.

This was in accordance with previous literature which states that the prevalence of tooth transposition varies considerably among different populations from $0.09 \%$ to $1.4 \%$ [31]. Transposition of the maxillary canine and first premolar presents a low prevalence of $0.03 \%$ in the population of Swedish school children 
[57], $0.13 \%$ of Arabian dental patients [45], 0.25\% of Scottish orthodontic patients [48] and $0.51 \%$ of individuals in a composite African sample [8]. In Japanese population, the reported prevalence of tooth transposition is $0.065 \%$ in the general population [3] and $0.660 \%$ in orthodontic patients [68]. Yilmaz et al found a prevalence of $0.380 \%$ of tooth transposition in a Turkish population [67] Buenviaje and Rapp reported a prevalence of transposed teeth of $0.080 \%$ in a population of children aged 2-12 years [7]. It seems that prevalence of transposition differs significantly according to race and region of sample selection.

In previous literature, it has been stated that the most common type of transposition is between the canine and first maxillary premolar, followed by transposition between the canine and the lateral incisor, central incisor and second premolar [51].

Contrastingly, the site of transposition in this study has a preponderance towards lateral incisor $(66.67 \%)$, followed by premolar $(33.33 \%)$.

This was similar to a study by Abu-Hussein Muhamad et al, where maxillary canine-lateral incisor transposition was found to have a higher frequency than maxillary canine-first premolar transposition in Israelian population [2].

The results of this study show a higher prevalence of maxillary canine transposition among adults $(0.41 \%)$, followed by adolescents $(0.2 \%)$ in the current population of patients undergoing orthodontic treatment. However, there was no statistically significant correlation between age and maxillary canine transposition and no previous studies have been carried out to explain the same.

Maxillary canine transposition has a female predilection with a prevalence of $0.41 \%$ out of $0.61 \%$ in this study but there is no statistical significance. Most of the previous studies had equivalent results in agreement with the findings of this study.In a study by Shapira $Y$ et al, females were found to have $60 \%$ more transposition than males[52]. Another study by Plunket D.J et al, showed that females had $63 \%$ of the total prevalence of maxillary canine transposition [37]. The prevalence of tooth transposition did not differ statistically between males $(0.20 \%)$ and females $(0.30 \%)$ $(\mathrm{P}=.884)$ in a meta-analysis by Moschos A. Papadopoulos et al. [33].

Patients with class I malocclusion had a higher prevalence of maxillary canine transposition $(0.41 \%)$, followed by patients with class II malocclusion $(0.2 \%)$ in the current study.

This was similar to a study by Kavadia-Tsatala $\mathrm{S}$ et al, where only three of the total group of 16 subjects with tooth transpositions (19\%) exhibited Angle Class II division 1 malocclusion and the rest $(81 \%)$ Angle Class I [24].

In a study of the relationship between tooth transposition and malocclusions, the frequency of prevalence was $0.5 \%$ for the Class III patients, while the Class II division 1 patients exhibited no transposition [5]. Our institution is passionate about high quality evidence based research and has excelled in various fields ( (Jayaseelan Vijayashree Priyadharsini 2019 [60]; Pc, Marimuthu, and Devadoss 2018 [34]; Ramesh et al. 2018 [41]; Ramadurai et al. 2019 [40]; Sridharan et al. 2019 [56]; Ezhilarasan, Apoorva, and Ashok Vardhan 2019 [15]; Mathew et al. 2020 [29]; Samuel 2021
[47]; R et al. 2020 [43]; Chandrasekar et al. 2020 [9]; J. Vijayashree Priyadharsini, Smiline Girija, and Paramasivam 2018 [38]). We hope this study adds to this rich legacy.

Even though a few studies show contradictory findings, the overall consensus was in agreement with the results of the present study.

The results of this study have to be interpreted with the geographic limitation of the study population and the sample size selected. Hence it cannot be generalized to other populations of geographic and cultural variation.

\section{Conclusion}

Within the limits of this study, the overall prevalence of maxillary canine transposition in the South Indian population was $0.61 \%$. The most common site of transposition was lateral incisor followed by premolar, with a higher prevalence among adults, female population and patients with class 1 malocclusion. However, there was no statistical significance between age, gender, type of malocclusion and maxillary canine transposition.

\section{References}

[1]. Abitha T, Santhanam A. Correlation between bizygomatic and maxillary central incisor width for gender identification. Brazilian Dent Sci. 2019 Oct 31;22(4):458-66.

[2]. Abu-Hussein M, Watted N, Azzaldeen A, Yehia M, Awadi O, Abu-Hussein Y. Prevalence of Malocclusion and Impacted Canine in Arab Israelian Population (Arab48). Int J Pub Health Res. 2015;3(5):180-91.

[3]. Asakura, S., T. Okamito, H. Tamoto, S. Kumano, and Y. Murata. 1958. "Forty Cases of Tooth Transposition." The Dental Outlook 15 (979): 86.

[4]. Azeem RA, Sureshbabu NM. Clinical performance of direct versus indirect composite restorations in posterior teeth: A systematic review. J Conserv Dent. 2018 Jan-Feb;21(1):2-9. Pubmed PMID: 29628639.

[5]. Basdra EK, Kiokpasoglou MN, Komposch G. Congenital tooth anomalies and malocclusions: a genetic link? Eur J Orthod. 2001 Apr;23(2):145-51. Pubmed PMID: 11398552.

[6]. Budai M, Ficzere I, Gábris K, Tarjan I. A transzpozíció elófordulási gyakorisága a Semmelweis Egyetem Gyermekfogászati és Fogszabályozási Klinika ötéves beteganyagában [Frequency of transposition and its treatment at the Department of Pedodontics and Orthodontics of Semmelweis University in the last five years]. Fogorv Sz. 2003 Feb;96(1):21-4. Hungarian. Pubmed PMID: 12666391.

[7]. Buenviaje TM, Rapp R. Dental anomalies in children: a clinical and radiographic survey. ASDC J Dent Child. 1984 Jan-Feb;51(1):42-6. Pubmed PMID: 6583219.

[8]. Burnett SE. Prevalence of maxillary canine-first premolar transposition in a composite African sample. Angle Orthod. 1999 Apr;69(2):187-9. Pubmed PMID: 10227560.

[9]. Chandrasekar R, Chandrasekhar S, Sundari KKS, Ravi P. Development and validation of a formula for objective assessment of cervical vertebral bone age. Prog Orthod. 2020 Oct 12;21(1):38. Pubmed PMID: 33043408.

[10]. Chattopadhyay A, Srinivas K. Transposition of teeth and genetic etiology. Angle Orthod. 1996;66(2):147-52. Pubmed PMID: 8712493.

[11]. Chen F, Tang Y, Sun Y, Veeraraghavan VP, Mohan SK, Cui C. 6-shogaol, a active constiuents of ginger prevents UVB radiation mediated inflammation and oxidative stress through modulating $\mathrm{NrF} 2$ signaling in human epidermal keratinocytes (HaCaT cells). J Photochem Photobiol B. 2019 Aug; 197:111518. Pubmed PMID: 31202076.

[12]. Demir A, Basciftci FA, Gelgör IE, Karaman AI. Maxillary canine transposition. J Clin Orthod. 2002 Jan;36(1):35-7. Pubmed PMID: 11887640.

[13]. Dhinesh B, Bharathi RN, Lalvani JI, Parthasarathy M, Annamalai K. An experimental analysis on the influence of fuel borne additives on the single cylinder diesel engine powered by Cymbopogon flexuosus biofuel. Journal of the Energy Institute. 2017 Aug 1;90(4):634-45.

[14]. Dinesh SP, Arun AV, Sundari KK, Samantha C, Ambika K. An indigenously designed apparatus for measuring orthodontic force. J Clin Diagn Res. 2013 Nov;7(11):2623-6. Pubmed PMID: 24392423.

[15]. Ezhilarasan D, Apoorva VS, Ashok Vardhan N. Syzygium cumini extract in- 
duced reactive oxygen species-mediated apoptosis in human oral squamous carcinoma cells. J Oral Pathol Med. 2019 Feb;48(2):115-121. Pubmed PMID: 30451321

[16]. Felicita AS. Quantification of intrusive/retraction force and moment generated during en-masse retraction of maxillary anterior teeth using mini-implants: A conceptual approach. Dental Press J Orthod. 2017 SepOct;22(5):47-55. Pubmed PMID: 29160344.

[17]. Felicita AS. Orthodontic management of a dilacerated central incisor and partially impacted canine with unilateral extraction - A case report. Saudi Dent J. 2017 Oct;29(4):185-193. Pubmed PMID: 29033530.

[18]. Felicita AS. Orthodontic extrusion of Ellis Class VIII fracture of maxillary lateral incisor - The sling shot method. Saudi Dent J. 2018 Jul;30(3):265269. Pubmed PMID: 29942113.

[19]. Felicita AS, Chandrasekar S, Shanthasundari KK. Determination of craniofacial relation among the subethnic Indian population: a modified approach - (Sagittal relation). Indian J Dent Res. 2012 May-Jun;23(3):305-12. Pubmed PMID: 23059564

[20]. Girija SA, Jayaseelan VP, Arumugam P. Prevalence of VIM- and GIMproducing Acinetobacter baumannii from patients with severe urinary tract infection. Acta Microbiol Immunol Hung. 2018 Dec 1;65(4):539-550. Pubmed PMID: 30111160

[21]. Govindaraju L, Neelakantan P, Gutmann JL. Effect of root canal irrigating solutions on the compressive strength of tricalcium silicate cements. Clin Oral Investig. 2017 Mar;21(2):567-571. Pubmed PMID: 27469101.

[22]. Jain RK, Kumar SP, Manjula WS. Comparison of intrusion effects on maxillary incisors among mini implant anchorage, j-hook headgear and utility arch. J Clin Diagn Res. 2014 Jul;8(7):ZC21-4. Pubmed PMID: 25177631.

[23]. Kamisetty SK, Verma JK, Arun, Sundari S, Chandrasekhar S, Kumar A. SBS vs Inhouse Recycling Methods-An Invitro Evaluation. J Clin Diagn Res. 2015 Sep;9(9):ZC04-8. Pubmed PMID: 26501002.

[24]. Kavadia-Tsatala S, Sidiropoulou S, Kaklamanos EG, Chatziyanni A. Tooth transpositions associated with dental anomalies and treatment management in a sample of orthodontic patients. J Clin Pediatr Dent. 2003 Fall;28(1):1925. Pubmed PMID: 14604137.

[25]. Krishnan S, Pandian S, Kumar S A. Effect of bisphosphonates on orthodontic tooth movement-an update. J Clin Diagn Res. 2015 Apr;9(4):ZE01-5. Pubmed PMID: 26023659.

[26]. Laptook T, Silling G. Canine transposition--approaches to treatment. J Am Dent Assoc. 1983 Nov;107(5):746-8. Pubmed PMID: 6580334.

[27]. Maia FA, Maia NG. Unusual orthodontic correction of bilateral maxillary canine-first premolar transposition. Angle Orthod. 2005 Mar;75(2):266-76. Pubmed PMID: 15825794.

[28]. Manohar J. A Study on the Knowledge of Causes and Prevalance of Pigmentation of Gingiva among Dental Students. Indian Journal of Public Health Research \& Development. 2019 Aug 1;10(8).

[29]. Mathew MG, Samuel SR, Soni AJ, Roopa KB. Evaluation of adhesion of Streptococcus mutans, plaque accumulation on zirconia and stainless steel crowns, and surrounding gingival inflammation in primary molars: randomized controlled trial. Clin Oral Investig. 2020 Sep;24(9):3275-3280. Pubmed PMID: 31955271.

[30]. Muthukrishnan A, Warnakulasuriya S. Oral health consequences of smokeless tobacco use. Indian J Med Res. 2018 Jul;148(1):35-40. Pubmed PMID: 30264752 .

[31]. Onyeaso CO, Oneyeaso AO. Occlusal/dental anomalies found in a random sample of Nigerian schoolchildren. Oral Health Prev Dent. 2006;4(3):1816. Pubmed PMID: 16961026.

[32]. Pandian KS, Krishnan S, Kumar SA. Angular photogrammetric analysis of the soft-tissue facial profile of Indian adults. Indian J Dent Res. 2018 MarApr;29(2):137-143. Pubmed PMID: 29652003.

[33]. Papadopoulos MA, Chatzoudi M, Kaklamanos EG. Prevalence of tooth transposition. A meta-analysis. Angle Orthod. 2010 Mar;80(2):275-85. Pubmed PMID: 19905852

[34]. J PC, Marimuthu T, C K, Devadoss P, Kumar SM. Prevalence and measurement of anterior loop of the mandibular canal using CBCT: A cross sectional study. Clin Implant Dent Relat Res. 2018 Aug;20(4):531-534. Pubmed PMID: 29624863

[35]. Peck L, Peck S, Attia Y. Maxillary canine-first premolar transposition, associated dental anomalies and genetic basis. Angle Orthod. 1993 Summer;63(2):99-109. Pubmed PMID: 8498708.

[36]. Peck S, Peck L. Classification of maxillary tooth transpositions. Am J Orthod Dentofacial Orthop. 1995 May;107(5):505-17. Pubmed PMID: 7733060.

[37]. Plunkett DJ, Dysart PS, Kardos TB, Herbison GP. A study of transposed canines in a sample of orthodontic patients. Br J Orthod. 1998 Aug;25(3):2038. Pubmed PMID: 9800019

[38]. Vijayashree Priyadharsini J, Smiline Girija AS, Paramasivam A. In silico analysis of virulence genes in an emerging dental pathogen A. baumannii and related species. Arch Oral Biol. 2018 Oct;94:93-98. Pubmed PMID:
30015217.

[39]. Priyanka S, Kaarthikeyan G, Nadathur JD, Mohanraj A, Kavarthapu A. Detection of cytomegalovirus, Epstein-Barr virus, and Torque Teno virus in subgingival and atheromatous plaques of cardiac patients with chronic periodontitis. J Indian Soc Periodontol. 2017 Nov-Dec;21(6):456-460. Pubmed PMID: 29551863.

[40]. Ramadurai N, Gurunathan D, Samuel AV, Subramanian E, Rodrigues SJL. Effectiveness of 2\% Articaine as an anesthetic agent in children: randomized controlled trial. Clin Oral Investig. 2019 Sep;23(9):3543-3550. Pubmed PMID: 30552590

[41]. Ramesh A, Varghese S, Jayakumar ND, Malaiappan S. Comparative estimation of sulfiredoxin levels between chronic periodontitis and healthy patients - A case-control study. J Periodontol. 2018 Oct;89(10):1241-1248. Pubmed PMID: 30044495.

[42]. Ramesh Kumar KR, Shanta Sundari KK, Venkatesan A, Chandrasekar S. Depth of resin penetration into enamel with 3 types of enamel conditioning methods: a confocal microscopic study. Am J Orthod Dentofacial Orthop. 2011 Oct;140(4):479-85. Pubmed PMID: 21967934

[43]. R H, Ramani P, Ramanathan A, R JM, S G, Ramasubramanian A, K M. CYP2 C9 polymorphism among patients with oral squamous cell carcinoma and its role in altering the metabolism of benzo[a]pyrene. Oral Surg Oral Med Oral Pathol Oral Radiol. 2020 Sep;130(3):306-312. Pubmed PMID: 32773350 .

[44]. Rubika J, Felicita AS, Sivambiga V. Gonial angle as an indicator for the prediction of growth pattern. World Journal of Dentistry. 2015 Sep 1;6(3):161-

[45]. Ruprecht A, Batniji S, El-Neweihi E. The incidence of transposition of teeth in dental patients. J Pedod. 1985 Spring;9(3):244-9. Pubmed PMID: 3858501 .

[46]. Samantha C, Sundari S, Chandrasekhar S, Sivamurty G, Dinesh S. Comparative Evaluation of Two Bis-GMA Based Orthodontic Bonding Adhesives - A Randomized Clinical Trial. J Clin Diagn Res. 2017 Apr;11(4):ZC40 ZC44. Pubmed PMID: 28571259.

[47]. Samuel SR. Can 5-year-olds sensibly self-report the impact of developmental enamel defects on their quality of life? Int J Paediatr Dent. 2021 Mar;31(2):285-286. Pubmed PMID: 32416620.

[48]. Sandham A, Harvie H. Ectopic eruption of the maxillary canine resulting in transposition with adjacent teeth. Tandlaegebladet. 1985 Jan;89(1):9-11. Pubmed PMID: 3859032.

[49]. Shapira J, Chaushu S, Becker A. Prevalence of tooth transposition, third molar agenesis, and maxillary canine impaction in individuals with Down syndrome. Angle Orthod. 2000 Aug;70(4):290-6. Pubmed PMID: 10961778.

[50]. Shapira Y. Transposition of canines. J Am Dent Assoc. 1980 May;100(5):710 2. Pubmed PMID: 6928912

[51]. Shapira Y, Kuftinec MM. Tooth transpositions--a review of the literature and treatment considerations. Angle Orthod. 1989 Winter;59(4):271-6. Pubmed PMID: 2688487.

[52]. Shapira Y, Kuftinec MM. Maxillary tooth transpositions: characteristic features and accompanying dental anomalies. Am J Orthod Dentofacial Orthop. 2001 Feb;119(2):127-34. Pubmed PMID: 11174558.

[53]. Sheriff K, Santhanam A. Knowledge and Awareness towards Oral Biopsy among Students of Saveetha Dental College. Research Journal of Pharmacy and Technology. 2018;11(2):543-6

[54]. Sitharthan R, Sundarabalan CK, Devabalaji KR, Yuvaraj T, Mohamed Imran A. Automated power management strategy for wind power generation system using pitch angle controller. Measurement and Control. 2019 Mar;52(3-4):169-82

[55]. Sivamurthy G, Sundari S. Stress distribution patterns at mini-implant site during retraction and intrusion--a three-dimensional finite element study. Prog Orthod. 2016;17:4. Pubmed PMID: 26780464.

[56]. Sridharan G, Ramani P, Patankar S, Vijayaraghavan R. Evaluation of salivary metabolomics in oral leukoplakia and oral squamous cell carcinoma. J Oral Pathol Med. 2019 Apr;48(4):299-306. Pubmed PMID: 30714209.

[57]. Thilander B, Jakobsson SO. Local factors in impaction of maxillary canines. Acta Odontol Scand. 1968 May;26(2):145-68. Pubmed PMID: 5247251.

[58]. Umweni AA, Ojo MA. The frequency of tooth transposition in Nigerians, its possible aetiologic factors and clinical implications. J Dent Assoc S Afr. 1997 Sep;52(9):551-4. Pubmed PMID: 9461914

59]. Venu H, Raju VD, Subramani L. Combined effect of influence of nano additives, combustion chamber geometry and injection timing in a DI diesel engine fuelled with ternary (diesel-biodiesel-ethanol) blends. Energy. 2019 May 1;174:386-406.

[60]. Vijayashree Priyadharsini J. In silico validation of the non-antibiotic drugs acetaminophen and ibuprofen as antibacterial agents against red complex pathogens. J Periodontol. 2019 Dec;90(12):1441-1448. Pubmed PMID 31257588.

[61]. Vijayashree Priyadharsini J, Smiline Girija AS, Paramasivam A. In silico 
analysis of virulence genes in an emerging dental pathogen A. baumannii and related species. Arch Oral Biol. 2018 Oct;94:93-98. Pumed PMID: 30015217.

[62]. Vikram NR, Prabhakar R, Kumar SA, Karthikeyan MK, Saravanan R. Ball Headed Mini Implant. J Clin Diagn Res. 2017 Jan;11(1):ZL02-ZL03. Pubmed PMID: 28274084.

[63]. Viswanath A, Ramamurthy J, Dinesh SP, Srinivas A. Obstructive sleep apnea: awakening the hidden truth. Niger J Clin Pract. 2015 Jan-Feb;18(1):1-7. Pubmed PMID: 25511335.

[64]. Wang Y, Zhang Y, Guo Y, Lu J, Veeraraghavan VP, Mohan SK, Wang C, Yu X. Synthesis of Zinc oxide nanoparticles from Marsdenia tenacissima inhibits the cell proliferation and induces apoptosis in laryngeal cancer cells (Hep-2). J Photochem Photobiol B. 2019 Dec;201:111624. Pubmed PMID: 31722283.
[65]. Wu F, Zhu J, Li G, Wang J, Veeraraghavan VP, Krishna Mohan S, Zhang Q. Biologically synthesized green gold nanoparticles from Siberian ginseng induce growth-inhibitory effect on melanoma cells (B16). ArtifCells Nanomed Biotechnol. 2019 Dec;47(1):3297-3305. Pubmed PMID: 31379212.

[66]. Yaillen DM. Case report BC. Early identification and correction of transposed teeth. Angle Orthod. 1990 Spring;60(1):73-7. Pubmed PMID: 2316908.

[67]. Yilmaz HH, Türkkahraman H, Sayin MO. Prevalence of tooth transpositions and associated dental anomalies in a Turkish population. Dentomaxillofac Radiol. 2005 Jan;34(1):32-5. Pubmed PMID: 15709103.

[68]. Yoshida S, Suzuki A, Ito K, Tanne K. Current status of migrated tooth and clinical consideration for the orthodontic treatment. J Hiroshima Univ Dent Soc. 1995;27:266-74. 